\title{
Analisis Ta'widh terhadap Proses Penyelesaian Wanprestasi Barang Hilang di PT. JNE Kota Bandung
}

\author{
Amet Faisal Apriliady, Eva Misfah Bayuni, Muhammad Yunus \\ Program Studi Hukum Ekonomi Syariah, Fakultas Syariah, Universitas Islam Bandung \\ Jl. Tamansari No. 140116 \\ Ametfaisa1007@gmail.com,Evambayuni@gmail.com,yunus_rambe@yahoo.co.id
}

\begin{abstract}
Abstarct-A shipping company in carrying out its duties must be responsible for the agreement that has been agreed, because the shipment is not always run smoothly, such as goods that are not delivered, damaged or lost. At first glance in actual reality the company also provides dependents on goods in the event of default. But in reality, the lost or damaged items at PT. JNE compensation provided is only 10 times teh cost of sending one kilo of goods lost or damaged without calculating the weight of item. Therefore the problem formulation of this research is to find out the concept of ta'widh according to Wahbah AlZuhayli the process of setllement of defaults at PT. JNE and analysis of the settlement of defaults to the ta'widh process at PT. JNE.
\end{abstract}

This research method uses descriptive analysis with a qualitative approach that is to see the completion of the interpretation of the ta'widh process at PT. JNE.

Based on the conclusion of this study that the ta'widh process according to Wahbah Al-Zuhayli is like returning a broken object to be whole again, if it is difficult to do, then it is obligatory to replace it with the same object (of a kind) or with money. Completion of defaults to the ta'widh process at PT. JNE compensation (ta'widh) provided by PT. JNE to consumers or users of shipping services is not appropriate or only part of what is obtained by this is not appropriate as the opinion has been expressed by contemporary scholars Wahbah Al-Zuhayli.

Keywords-Performance-Ta'widh, Wahbah Al-Zuhayli

\begin{abstract}
Abstrak-Suatu perusahaan pengiriman barang dalam menjalankan tugasnya harus bertanggung jawab terhadap perjanjian yang telah disepakati, karena pengiriman yang dilakukan tidaklah selalu berjalan dengan lancar, seperti barang yang dikirim tidak sampai, rusak atau pun hilang. Sekilas, pada realitas yang sebenarnya, pihak perusahaan juga memberikan tanggungan terhadap barang apabila terjadinya wanprestasi. Namun pada realitanya barang yang hilang atau rusak di PT. JNE ganti rugi yang diberikan hanya sebesar 10 kali dari biaya kirim satu kilo terhadap barang yang hilang atau rusak tanpa menghitung berat barang tersebut. Oleh karena itu rumusan masalah dari penelitian ini adalah untuk mengetahui konsep ta'widh menurut Wahbah Al-Zuhayli, proses penyelesaian wanprestasi di PT. JNE dan analisis penyelesaian wanprestasi terhadap proses ta'widh di PT. JNE.
\end{abstract}

Metode penelitian ini menggunakan analisis dekriptif dengan pendekatan kualitatif yaitu untuk melihat penyelesaian wanpretasi terhadap proses ta'widh di PT. JNE.
Berdasarkan kesimpulan dari penelitian ini bahwa proses ta'widh menurut Wahbah Al-Zuhayli yaitu seperti mengembalikan benda yang dipecahkan menjadi utuh kembali, apabila hal tersebut sulit dilakukan maka wajib menggantinya dengan benda yang sama (sejenis) atau dengan uang. Penyelesaian wanprestasi terhadap proses ta'widh di PT. JNE apabila ada barang yang hilang hanya diganti dengan $10 \mathrm{kali}$ biaya kirim saja. Ganti rugi (ta'widh) yang diberikan pihak PT. JNE kepada konsumen atau pengguna jasa pengiriman tidak sesuai atau hanya sebagian yang di dapat oleh yang mana ini tidak sesuai seperti pendapat yang telah dikemukakan oleh ulama kontemporer Wahbah Al-Zuhayli.

Kata Kunci : Wanprestasi, Ta'widh, Wahbah Al-Zuhayli

\section{PENDAHULUAN}

Suatu perusahaan pengiriman barang dalam menjalankan tugasnya harus bertanggung jawab terhadap perjanjian yang telah disepakati, karena pengiriman yang dilakukan tidaklah selalu berjalan dengan lancar, seperti barang yang dikirim tidak sampai, rusak atau pun hilang. 1 Apabila perjanjian yang telah disepakati itu dilanggar, maka dapat diajukan gugatan wanprestasi, karena ada hubungan kontraktual antara pihak yang menimbulkan kerugian dan pihak yang menderita kerugian. 2 Sekilas, pada realitas yang sebenarnya, pihak perusahaan juga memberikan tanggungan terhadap barang apabila terjadinya wanprestasi. Salah satu perusahaan pengiriman barang yang memberi tanggungan terhadap keselamatan barang konsumen yaitu PT. JNE ( PT. TIKI Jalur Nugraha Ekakurir). Di sini memang pihak JNE memberikan tanggungan terhadap barang yang hilang/rusak, yaitu dengan memberikan ganti rugi.

Namun pada realitanya barang yang hilang atau rusak di PT. JNE ganti rugi yang diberikan hanya sebesar 10 kali dari biaya kirim satu kilo terhadap barang yang hilang atau rusak tanpa menghitung berat barang tersebut. Kecuali dengan menggunakan asuransi, maka akan digantikan seharga barangnya, dengan biaya asuransi yaitu sebesar $0,2 \%$ dari harga barang ditambah administrasinya sebesar 
Rp 5000,-.3 Tapi ganti rugi yang diberikan oleh PT JNE tidak sesuai dengan yang telah diatur oleh hukum positif dan hukum Islam, atau dapat disimpulkan bahwasanya pihak JNE hanya memberikan ganti rugi sebagian.

Bahkan syariah Islam pun melindungi kepentingan semua pihak yang bertransaksi, sehingga tidak ada satu pihak pun yang di rugikan hak-haknya dan kerugian yang benar-benar dialami secra riil oleh para pihak dalam transaksi wajib di ganti oleh pihak yang menimbulkan kerugian tersebut.

\section{LANDASAN TEORI}

\section{A. Teori Wadiah}

Wadiah adalah segala sesuatu yang dititipkan baik uang ataupun barang lainnya kepada seseorang yang harus menjaganya dan harus mengembalikannya kepada pemiliknya ketika diminta.4 Fuqaha telah bersepakat mengenai hukum kebolehan menitip dan meminta menitikan barang kepada seseorang, sementara di mustahabkan (disunatkan) pihak yang diberikan amanah untuk menerima titipan itu.5

Terjadinya akad wadi'ah (penitipan barang) atas dasar saling percaya diantara kedua belah pihak, dan titipan tersebut merupakan amanah yang berada di tangan penerima titipan, sehingga dia tidak berkewajiban mengganti titipan kecuali akibat kelalaian dalam penjagaan. Apabila si penerima titipan lalai dalam mencegah sesuatu yang dapat merusak titipan tersebut, maka dia berkewajiban menanggung atau mengganti titipan itu.6

Teori Wanprestasi

Wanprestasi adalah ketiadaan suatu prestasi di dalam hukum perjanjian, berati suatu hal yang baru dilaksanakan sebagai isi dari suatu perjanjian. Barangkali dalam Bahasa Indonesia dapat dipakai istilah pelaksanaan janji prestasi dan ketiadaan pelaksanaan janji untuk wanprestasi.7 Adanya wanprestasi adalah bentuk sikap pengingkaran salah seorang yang berakad atau bertransaksi yang tidak menjalankan kewajiban berupa prestasi dari apa yang menjadi kesepakatan dalam perjanjian antara pihak yang bersangkutan. Sesuatu yang dilaksanakan itulah yang dinamakan prestasi. Jadi wujud dari prestasi adalah melakukan perbuatan tertentu, apabila salah satu pihak tidak melakukan kewajibannya baik kelalaian atau kesengajaan maka pihak tersebut dinyatakan atau di anggap wanprestasi. Jadi pengertian dalam melaksanakan kewajiban adalah memenuhi prestasi tersebut. Adapun bentuk-bentuk wanprestasi yaitu :
1. Tidak memenuhi prestasi sama sekali, sehubungan dengan debitur yang tidak memenuhi prestasinya maka dikatakan debitur tidak memenuhi prstasi sama sekali.

2. Memenuhi prestasi tetapi tidak tepat waktunya, apabila prestasi debitur masih dapat diharapkan pemenuhannya, maka debitur dianggap memenuhi prestasi tetapi tidak tepat waktunya.

3. Memenuhi prestasi tetapi tidak sesuai atau keliru, debitur yang memenuhi prestasi tapi keliru, apabila prestasi keliru tersebut tidak dapat diperbaiki lagi maka debitur dikatakan tidak memenuhi prestasi sama sekali.

Menurut Subekti, bentuk wanprestasi ada empat macam yaitu :

1. Tidak melakukan apa yang disanggupi atau dilakukan.

2. Melaksanakan apa yang dijanjikannya tetapi tidak sebagaimana dijanjikannya.

3. Melakukan apa yang dijanjikannya tetapi terlambat.

4. Melaksanakan sesuatu yang menurut perjanjian tidak boleh dilakukan.

\section{B. Teori Ta'widh}

Kata Ta'widh berasal dari kata 'Iwadh yang artinya ganti rugi atau kompensasi. Sedangkan Ta'widh secara bahasa berarti mengganti rugi atau membayar kompensasi.8 Adanya Dhaman (tanggung jawab) untuk menggantikan atas sesuatu yang merugikan dasarnya adalah kaidah hukum Islam.

Menurut pendapat Wahbah Al-Zuhayli mengenai Ta'widh dalam bahasa adalah ganti rugi atau kompensasi. Secara istilah definisi dari Ta'widh yang dikemukakan oleh Ulama Fiqh kontemporer Wahbah Al-Zuhayli adalah:

Artinya : Ketentuan umum yang berlaku pada ganti rugi dapat berupa menutup kerugian dalam bentuk uang (dharar) seperti memperbaiki dinding, memperbaiki benda yang dirusak menjadi utuh kembali seperti semula selama dimungkinkan, seperti mengembalikan benda yang dipecahkan menjadi utuh kembali. Apabila hal tersebut sulit dilakukan maka wajib menggantinya dnegan benda yang sama (sejenis) atau dengan uang. 9

Dari pernyataan Wahbah Al-Zuhayly sudah jelas bahwa ganti rugi sebenarnya sesuai dengan ajaran Islam adalah mengganti barang yang rusak atau hilang sesuai dengan barang yang sama. Kalu tidak bisa dengan barang yang sama maka dnegan uang yang senilai dengan harga barang yang hilang atau rusak tersebut. Dengan aturan ganti rugi yang dikemukakan oleh Wahbah Al-Zuhayly menjauhkan kerugian dari sebelah pihak.

Dan pada umumnya sudah jelas ganti rugi yang dikemukakan dari seorang Ulama Kontemporer yaitu Wahbah AL-Zuhayli sangat bersamaan dengan maksud dan tujuan terhadap ganti rugi menurut hukum positif yaitu suatu kewajiban kerugian yang dibebankan kepada orang 
yang telah bertindak melawan hukum dan menimbulkan kerugian pada orang lain karena kesalahannya. Rukun ta'widh diantaranya yaitu :

1. Orang yang menjamin.

2. Orang yang berpiutang.

3. Orang yang berhutang.

4. Objek jaminan barang berupa uang atau barang.

5. Sighat

Sedangkan Syarat Ta'widh yaitu :

1. Pertama, dari orang yang menjamin syaratnya orang yang menjamin harus orang yang berakal baligh, merdeka dalam mengelola harta bendanya dan atas kehendaknya sendiri. Dengan demikian, anak-anak, orang gila dan orang ynag berada dibawah pengampuan tidak dapat menjadi penjamin.

2. Kedua, orang ynag berpiutang syaratnya adalah diketahui oleh penjamin. Sebab watak manusia berbeda-beda dalam menghadapi orang yang berhutang ada yang keras dan ada yang lunak. Terutama sekali dimaksudkan untuk menghindari kekecewaan di belakang hari bagi penjamin.

3. Ketiga, orang yang berhutang disyaratkan baginya kerelaan terhadap penjamin karena pada prinsipnya hutang itu harus lunas baik orang yag berhutang rela maupun tidak namun lebih baik dia rela.

4. Keempat, objek jaminan hutang berupa uang atau barang disyaratkan bahwa keadaan diketahui dan telah ditetapkan. Oleh sebab itu, tidak sah daman (jaminan) jika objek jaminan hutang tidak diketahui dan belum ditetapkan, karena ada kemungkinan hal ini ada gharar atau tipuan.

5. Kelima, sighat yaitu pernyataan yang diucapkan penjamin disyaratkan keadaan sighat mengandung ucapan jaminan tidak digantungkan pada sesuatu. Sighat hanya diperlukan bagi pihak penjamin. Dengan demikian damman adalah pernyataan sepihak saja.

\section{Penerapan Ta'widh Pada Akad Wadiah}

Maka hubungan wadiah dan Ta'widh dalam perjanjian sangatlah memiliki keterkaitan yang sangat kuat karena timbulnya suatu kerugian disebabkan karena adanya salah satu pihak yang tidak memenuhi perjanjian dalam akad tersebut. Dalam hal ini lah yang dikatakan wanprestasi terhadap ke salah satu pihak dalam perjanjian dan menimbulkan kerugian. Oleh karena itu, di haruskan kepada pihak yang mengingkari atau merugikan berhak memberikan Ta'widh kepada yang dirugikan

\section{Metode Penelitian}

Jenis Penelitian yang digunakan dalam penulisan skripsi ini adalah penelitian kualitatif,yaitu metode yang tidak mengadakan perhitungan matematis,statistik dan sebagainya melainkan penekanan ilmiah10. Sifat penelitian yang digunakah adalah pendekatan yuridis empiris bertujuan untuk mengkaji ketentuan hukum yang berlaku serta apa yang terjadi dalam kenyataan di masyarakat 11 . Atau dengan kata lain yaitu suatu penelitian yang dilakukan terhadap keadaan sebenarnya atau keadaan nyata yang terjadi di masyarakat dengan maksud untuk mengetahui dan menemukan fakta-fakta yang dibutuhkan. Setelah data yang dibutuhkan terkumpul kemudian menuju kepada identifikasi dan dilakukan penyelesaian masalah 12. Sedangkan sumber data berupa data primer dan data sekunder. Data primer dalam penelitian ini adalah datadata PT. JNE. Data sekunder adalah studi kepustakaan berupa hasil penelitian yang berwujud laporan dan sebagainya yang berkaitan dengan wanprestasi dan ta'widh (ganti rugi).

\section{HASIL DAN PEMBAHASAN}

Proses penyelesaian wanprestasi barang yang hilang atau rusak di PT. JNE membuat laporan terlebih dahulu di gerai pengiriman yang digunakan sebelumnya, selanjutnya pihak gerai memeriksa terlebih dahulu seluruh barang yang keluar melalui sistem. Apabila barang itu tidak ditemukan di gerai pihak gerai akan berkoordinasi dengan pihak kantor pusat dimana setiap barang yang masuk maupun keluar akan di sortir terlebih dahulu sebelum di distribusikan, pihak kantor pusat akan memeriksa barang tersebut melalui sistem dengan menggunakan nomor resi apabila barang tersebut tidak bisa dilacak keberadaannya maka pihak JNE akan melakukan pemberian ganti rugi sesuai dengan ketentuan yaitu sebesar 10 kali lipat biaya ongkos pengiriman yang akan diberikan secara langsung kepada konsumen melalui gerai pengiriman dimana konsumen pertama kali menitipkan barangnya dengan mengisi form yang telah disediakan.

Apabila barang tersebut rusak pada saat serah terima maka konsumen bisa melakukan pengaduan di gerai terdekat yang selanjutnya pihak gerai akan berkoordinasi dengan pihak-pihak yang bersangkutan. Barang yang rusak pun akan diganti maksimal 10 kali lipat biaya ongkos kirim, dengan langkah yang sama dengan proses penyelesaian wanprestasi barang yang rusak. 
Adapun proses dari ganti rugi yang dilakukan PT. JNE yaitu :

1. Melakukan klaim (klaim atas kiriman hanya dapat diajukan oleh pengirim).

\section{DAFTAR PUSTAKA}

2. Pengajuan klaim mengikuti seluruh ketentuan yang diatur oleh PT. JNE.

3. Batas waktu maksimum pengajuan klaim selambatlambatnya 14 hari kalender terhitung sejak kiriman seharusnya diterima.

4. Pengajuan klaim tidak akan diproses bila melebihi dari 14 hari kalender sejak kiriman seharusnya diterima.

5. Biaya ganti rugi tergantung kesepakatan antara konsumen dan karyawan agen PT. JNE akan dilakukan secara cash maupun secara transfer bank.13

\section{SimPUlAN}

Setelah penulis melakukan penelitian mengenai Analisis Ta'widh Terhadap Proses Penyelesaian Wanprestasi Barang Hilang Di PT. JNE Kota Bandung, maka penulis dapat mengambil kesimpulan sebagai berikut :

1. Menurut pendapat Wahbah Al-Zuhayli mengenai Ta'widh dalam bahasa adalah ganti rugi atau kompensasi. Secara istilah definisi dari Ta'widh yang dikemukakan oleh Ulama Fiqh kontemporer Wahbah Al-Zuhayli adalah ketentuan umum yang berlaku pada ganti rugi dapat berupa menutup kerugian dalam bentuk uang (dharar) seperti memperbaiki benda yang dirusak menjadi utuh kembali seperti semula selama dimungkinkan, seperti mengembalikan benda yang dipecahkan menjadi utuh kembali. Apabila hal tersebut sulit dilakukan maka wajib menggantinya dengan benda yang sama (sejenis) atau dengan uang.

Apabila terdapat barang yang rusak atau hilang PT. JNE memberikan ganti rugi kepada konsumen (pihak yang dirugikan) berupa pengembalian uang maksimal sebesar 10 kali lipat dari biaya kirim, dapat dikatakan ganti rugi yang diberikan PT. JNE hanya sebagian. Penggantian rugi yang diberikan oleh PT. JNE hanya mengikuti harga terendah. Begitu juga dengan dokumen, apabila dokumen hilang akan diganti dengan penerbitan kembali dokumen tersebut, bukan nominal harga dokumen.

Jari penyelesaian wanprestasi terhadap proses ta'widhDilihat d di PT. JNE, bahwa ganti rugi(ta'widh) yang diberikan pihak PT. JNE kepada konsumen atau pengguna jasa pengiriman tidak sesuai atau hanya sebagian yang di dapat oleh konsumen karna ganti rugi (ta'widh) yang diberikan oleh pihak PT. JNE hanya sebesar maksimal 10 kali lipat ongkos kirim saja yang mana ini tidak sesuai seperti pendapat yang telah dikemukakan oleh ulama kontemporer Wahbah Al-Zuhayli.

[1] Buku

[2] Maleong, L. J. (2000). Metode Penelitian Kualitatif. Bandung: PT. Remaja Rosda Karya.

[3] Suharnoko. (2004). Hukum Perjanjian Teori Dan Analisis Kasus. Jakarta: Kencana.

[4] Jafri, S. (2008). Fiqh Muamalah. Pekanbaru: Suska Press.

[5] Mirru, A. (2008). Hukum Perikatan. Jakarta: Rajawali Pers.

[6] Muhammad, A. K. (1986). Hukum Perjanjian. Bandung: PT. Alumni.

[7] Nasution. (2008). Metode research (penelitian Ilmiah). Jakarta: Bumi Aksara.

[8] Prodjodikoro, W. (1979). Asas-Asas Hukum Perdata Internasional. Bandung: Peneliti Sumur Bandung.

[9] Zuhaili, W. (2010). Fiqih Imam Syafi'i. Jakarta: Almahira.

[10]

[11] Wawancara

[12] Muthy Hanifah, Karyawan PT. JNE Kota Bandung Tanggal 7 November 2019 